\title{
Kajian Program, Implementasi, dan Evaluasi Kurikulum 2013 SD Di Kecamatan Cina Kabupaten Bone
}

\author{
Abd. Haling ${ }^{1}$, Abd. Hakim ${ }^{2}$ \\ ${ }^{1,2}$ Teknologi Pendidikan, Fakultas Ilmu Pendidikan, Universitas Negeri Makassar \\ ${ }^{1}$ Abd.haling@unm.ac.id, \\ ªbdul.hakim7308@unm.ac.id
}

\begin{abstract}
ABSTRAK
Tujuan penelitian adalah (1) mengetahui gambaran program pembelajaran berbasis K.13 bagi guru SD, (2) mengetahui gambaran implementasi program pembelajaran berbasis K.13 bagi guru SD, (3) mengetahui gambaran evaluasi proses dan hasil penerapan K.13 bagi guru SD. Jenis penelitian ini adalah penelitian deskriptif (descriptif research). Desain penelitian adalah memadukan pendekatan kuantitatif dan kualitatif (mixed research design). Data kuantitatif adalah data tentang dimensi-dimensi setiap program dan implementasi, dan evaluasi program pembelajaran dengan menggunakan lembar kajian. Sebagai sumber informasi adalah guru dan kepala sekolah. Data kualitatif adalah yang dikumpulkan dengan menggunakan tiga pendekatan, yaitu pengamatan dan wawancara, dan dokumentasi. Dapatan kajian digunakan sebagai data empiris tentang kondisi riil tentang program, pelaksanaan, dan evaluasi program berbasis K.13. Hasil penelitian menunjukkan bahwa: (1) pengembangan program pembelajaran berbasis K.13 berada pada kategori "baik", (2) gambaran penerapan program berbasis K.13 bervariasi, yaitu masih terdapat beberapa guru menggunakan program pembelajaran dengan buatan KKG, Diknas, dan yang bersumber dari internet. Implementasi kurikulum dalam pelaksanaan pembelajaran, yaitu berkategori "kurang". (3) Gambaran proses dan hasil belajar penerapan K.13 bagi guru SD, berkategori "kurang". Dengan demikian disarankan kepada para pengambil kebijakan hendaknya melakukan pembinaan dan pengembangan kearah penyempurnaan dalam pelaksanaan kurikulum tahun 2013.
\end{abstract}

Kata kunci: Kajian program, implementasi, dan evaluasi kurikulum 2013

\section{ABSTRACT}

This research aimed (1) to find out learning programs based on 2013 curriculum for elementary school teachers, (2) to find out implementation of the programs based on 2013 curriculum for elementary school teachers, (3) to find out process and result evaluation of 2013 curriculum for elementary school teachers. This study was descriptive research. This research was conducted in order to comprehend the problems in learning programs development, programs implementation, and evaluation of learning programs implementation based on 2013 curriculum. This study employed quantitative and qualitative designs (mixed research design). The quantitative data were in relation to dimesnsions of every program as well as the implementation, and evalutation of learning programs which were obtained by using questioner. The respondents were teachers and head master in the school. The qualitative data were collected by using three approaches which were observation, interview, and documentation. The finding was used as empiric data about real condition of implementation and evaluation of learning program based on 2013 curriculum. The finding of the research showed that: (1) learning program development based on 2013 curriculum was categorized as "good", (2) learning program implementation based on 2013 curriculum was varied that some teachers used learning program made by teachers work group, National Education, and program which are obtaibed from internet, the curriculum implementation in learning process was categorized as "poor", (3) learning process and result based on 2013 curriculum for elementary school teachers was categorized as "poor". Therefore, it was suggested to the policy maker to provide coaching and development to the perfection of 2013 curriculum implementation

Keywords: Program review, implementation, and evaluation of the 2013 curriculum 


\section{PENDAHULUAN}

Setiap negara mempunyai tujuan pendidikan sebagai tumpuan umum dari segala aktivitas pendidikan. Kurikulum memegang peranan penting dalam upaya pencapaian tujuan pendidikan tersebut. Kurikulum mengandung rangkaian pengalaman belajar dalam bentuk tingkah laku (Sudirman, 2012). Dalam kurikulum 2013, salah satu pengalaman belajar yang hendak dicapai dalam pembelajaran adalah pencapaian sikap spiritual dan sikap sosial bagi siswa pada setiap lembaga pendidikan. Kurikulum ini, penekanannya pada pengembangan kompetensi pengetahuan, keterampilan, dan sikap peserta didik secara holistik (seimbang). Kompetensi tersebut ditagih dalam rapor dan merupakan penentu kenaikan kelas dan kelulusan peserta didik (Kemdikbud, 2013)

Kompetensi pengetahuan peserta didik yang dikembangkan meliputi: (a) mengetahui, (b) memahami, (c) menerapkan, (d) menganalisis, dan (e) mengevaluasi agar menjadi pribadi yang menguasai ilmu pengetahuan, teknologi, seni, budaya, dan berwawasan kemanusiaan, kebangsaan, dan kenegaraan, serta peradaban. Kompetensi keterampilan peserta didik yang akan dikembangkan meliputi: mengamati, menanya, mencoba, mengolah, menyaji, menalar, dan mencipta agar menjadi pribadi yang berkemampuan pikir dan tindak yang efektif dan kreatif dalam ranah konkrit dan abstrak. Kompetensi sikap peserta didik yang akan dikembangkan meliputi menerima, menjalankan, menghargai, menghayati, melaksanakan sehingga menjadi pribadi yang beriman, berakhlak mulia, percaya diri, dan bertanggung jawab dalam berinteraksi secara efektif dengan lingkungan sosial, alam sekitar, serta dunia dan peradabannya (Kemdikbud, 2013). Ketiga kompetensi tersebut, menjadi sasaran utama dalam pembelajaran dan dilakukan secara seimbang. Penerapan kurikulum sebelum Kurikulum 2013 dalam implementasinya, guru pada umumnya tidak mengembangkan kompetensi keterampilan dan sikap secara eksplisit, mungkin karena tidak ditagih dalam rapor sehingga tidak merupakan penentu kenaikan kelas dan kelulusan peserta didik.

Pada Kurikulum 2013, penyusunan kurikulum dimulai dengan menetapkan SKL berdasarkan kesiapan peserta didik, tujuan pendidikan nasional, dan kebutuhan. Setelah kompetensi ditetapkan, kemudian ditentukan kurikulumnya yang terdiri dari kerangka dasar kurikulum dan struktur kurikulum. Satuan pendidikan dan guru tidak diberikan kewenangan menyusun silabus, tetapi disusun pada tingkat nasional. Guru lebih diberikan kesempatan mengembangkan proses pembelajaran tanpa harus dibebani dengan tugas-tugas penyusunan silabus yang memakan waktu yang banyak dan memerlukan penguasaan teknis penyusunan yang memberatkan guru.

Uraian di atas, memberi penekanan bahwa tugas guru dalam penerapan K.13 pada dasarnya berkaitan dengan pengembangan proses pembelajaran. Pengembangan program pembelajaran ini terdapat tiga bidang tugas guru yaitu: (1) pengembangan disain pembelajaran; (2) implementasi; dan (3) evaluasi pelaksanaan pembelajaran.

Tugas guru dalam pengembangan program pembelajaran, guru dituntut untuk menghasilkan program pembelajaran berupa program tahunan, semester, pekan efektif, RPP, dan LKS. Selanjutnya sebagai tugas guru yang berkaitan dengan implementasi K.13 sasarannya adalah menghasilkan pengalaman belajar bagi peserta didik. Untuk mewujudkan hal tersebut, guru harus lebih awal mempersiapkan rancangan pembelajaran dengan pedoman pada kurikulum yang berlaku. Penyusunan rancangan pelaksanaan pembelajaran, sebagai usaha untuk mewujudkan kegiatan nyata dalam proses pembelajaran. Penyusunan rancangan pembelajaran merupakan tugas guru yang harus dikembangkan berdasar pada setiap $\mathrm{KI} / \mathrm{KD}$ /pokok bahasan. Rancangan pembelajaran ini hendaknya dibuat sebelum guru melaksanakan pembelajaran dengan mengacu pada kurikulum yang berlaku.

Program yang telah dihasilkan dan diimplementasikan dalam proses pembelajaran, selanjutnya dilakukan evaluasi. Istilah evaluasi dapat saja kita maknai upaya memahami dan memperbaiki suatu kegiatan. Evaluasi kurikulum berarti upaya memahami dan memperbaiki pelaksanaan kurikulum. Evaluasi kurikulum selalu mencakup penetapan baikburuknya terhadap pelaksanaan kurikulum berdasarkan kriteria tertentu. Evaluasi kurikulum merupakan salah satu langkah penting dalam rangkaian usaha memperoleh kurikulum yang baik, sebagai mata rantai dalam desain-implementasi-evaluasi kurikulum. Melalui evaluasi kurikulum akan diperoleh balikan yang tepat untuk menyempurnakan yang sedang atau telah dikembangkan itu dengan mengadakan 
berbagai revisi atau perbaikan. Evaluasi kurikulum dapat dilakukan dalam rangka pengembangan kurikulum yaitu sebelum kurikulum itu diimplementasikan, tetapi dapat juga dilakukan setelah kurikulum diimplementasikan. Evaluasi kurikulum dalam tahap pengembangan dapat dilakukan dengan mereview "draft" kurikulum yang telah selesai disusun oleh tim pengembang dalam rangka uji kesahan uji coba terbatas (pilot testing) atau pun uji coba lapangan (field testing) dari kurikulum yang telah dikembangkan. Evaluasi pada tahap ini termasuk kawasan evaluasi perencanaan program. Evaluasi setelah kurikulum diimplementasikan termasuk kawasan evaluasi monitoring dan atau evaluasi dampak (impact) (Sulo, 1997).

\section{a. Kurikulum Tahun 2013}

Pada tahun 2013 perubahan kurikulum kembali terjadi untuk SD, SMP, SMA, dan SMK. Kurikulum ini penekanan pada pengembangan kompetensi pengetahuan, keterampilan, dan sikap peserta didik secara holistik (seimbang). Kompetensi tersebut ditagih dalam rapor dan merupakan penentu kenaikan kelas dan kelulusan peserta didik (Kemendikbud, 2013)

Kompetensi pengetahuan peserta didik yang dikembangkan meliputi mengetahui, memahami, menerapkan, menganalisis, dan mengevaluasi agar menjadi pribadi yang menguasai ilmu pengetahuan, teknologi, seni, budaya, dan memiliki wawasan kemanusiaan, kebangsaan, dan kenegaraan, serta peradaban. Kompetensi keterampilan peserta didik yang dikembangkan meliputi mengamati, menanya, mencoba, mengolah, menyaji, menalar, dan mencipta agar menjadi pribadi yang berkemampuan pikir dan tindak yang efektif dan kreatif dalam ranah konkrit dan abstrak. Kompetensi sikap peserta didik yang dikembangkan meliputi menerima, menjalankan, menghargai, menghayati, melaksanakan sehingga menjadi pribadi yang beriman, berakhlak mulia, percaya diri, dan bertanggung jawab dalam berinteraksi secara efektif dengan lingkungan sosial, alam sekitar, serta dunia dan peradabannya (Kemdikbud, 2013). Ketiga kompetensi tersebut, menjadi sasaran utama dalam pembelajaran dan dilakukan secara seimbang. Penerapan kurikulum sebelum Kurikulum 2013 dalam implementasinya, guru pada umumnya tidak mengembangkan kompetensi keterampilan dan sikap secara eksplisit, mungkin karena tidak ditagih dalam rapor sehingga tidak merupakan penentu kenaikan kelas dan kelulusan peserta didik.

Perlu dipahami bahwa pengembangan kurikulum 2013 merupakan langkah lanjutan pengembangan KBK tahun 2004 dan KTSP tahun 2006. Di dalam kerangka pengembangan kurikulum 2013, hanya empat standar yang berubah, yaitu SKL, Standar Proses, Standar Isi, dan Standar Penilaian. SKL adalah kriteria mengenai kualifikasi kemampuan lulusan yang mencakup sikap, pengetahuan, dan keterampilan. Standar Isi adalah kriteria mengenai ruang lingkup materi dan tingkat kompetensi untuk mencapai Kompetensi Lulusan pada jenjang dan jenis pendidikan tertentu. Standar Proses adalah kriteria mengenai pelaksanaan pembelajaran pada satu satuan pendidikan untuk mencapai SKL. Standar Penilaian Pendidikan adalah kriteria mengenai mekanisme, prosedur, dan instrumen penilaian hasil belajar peserta didik.

Pada Kurikulum 2013, penyusunan kurikulum dimulai dengan menetapkan SKL berdasarkan kesiapan peserta didik, tujuan pendidikan nasional, dan kebutuhan. Setelah kompetensi ditetapkan, kemudian ditentukan kurikulumnya yang terdiri dari kerangka dasar kurikulum dan struktur kurikulum. Satuan pendidikan dan guru tidak diberikan kewenangan menyusun silabus, tetapi disusun pada tingkat nasional. Guru lebih diberikan kesempatan mengembangkan proses pembelajaran tanpa harus dibebani dengan tugas-tugas penyusunan silabus yang memakan waktu yang banyak dan memerlukan penguasaan teknis penyusunan yang memberatkan guru.

Kurikulum 2013 dirancang dengan beberapa karakteristik sebagai berikut: (1) Mengembangkan keseimbangan antara sikap spiritual dan sosial, pengetahuan dan keterampilan, serta menerapkannya dalam berbagai situasi di sekolah dan masyarakat; (2) Menempatkan sekolah sebagai bagian dari masyarakat yang memberikan pengalaman belajar agar peserta didik mampu menerapkan apa yang dipelajari di sekolah ke masyarakat dan memanfaatkan masyarakat sebagai sumber belajar; (3) Memberi waktu yang cukup leluasa untuk mengembangkan berbagai sikap, pengetahuan, dan keterampilan; (4) Mengembangkan kompetensi yang dinyatakan dalam bentuk Kompetensi Inti kelas yang dirinci lebih lanjut dalam kompetensi dasar mata pelajaran; (5) Mengembangkan Kompetensi Inti kelas menjadi unsur pengorganisasi (organizing elements) 
Kompetensi Dasar. Semua KD dan proses pembelajaran dikembangkan untuk mencapai kompetensi yang dinyatakan dalam KI; (6) Mengembangkan Kompetensi Dasar berdasar pada prinsip akumulatif, saling memperkuat (reinforced) dan memperkaya (enriched) antarmata pelajaran dan jenjang pendidikan (organisasi horizontal dan vertikal).

Dalam kurikulum 2013, proses pembelajaran menggunakan pendekatan saintifik, yaitu pembelajaran yang mendorong peserta didik agar lebih mampu dalam mengamati, menanya, mengumpulkan informasi, mengasosiasi atau menalar, dan mengomunikasikan. Hasil akhirnya adalah peningkatan dan keseimbangan antara soft skills serta hard skills peserta didik yang meliputi aspek kompetensi sikap, keterampilan, dan pengetahuan. Kemudian model pembelajaran yang diperlukan adalah yang memungkinkan terbudayakannya kecakapan berpikir sains, terkembangkannya "sciense of inquiry" dan kemampuan berpikir kreatif peserta didik. Model pembelajaran harus mampu menghasilkan kemampuan untuk peserta didik, bukan saja diperolehnya sejumlah pengetahuan, keterampilan, dan sikap, tetapi yang lebih penting adalah bagaimana hal itu diperoleh peserta didik.

Penguatan materi pada Kurikulum 2013 dilakukan dengan pengurangan materi yang tidak relevan serta pendalaman dan perluasan materi yang relevan bagi peserta didik. Juga menambahkan materi yang dianggap penting dalam perbandingan internasional, serta penguatan tujuan pembelajaran yang ingin dicapai. Secara umum, perbaikan Kurikulum 2013 bertujuan agar selaras antara ide, desain, dokumen, dan pelaksanaannya. Secara khusus, perbaikan Kurikulum 2013 bertujuan menyelaraskan KI-KD, silabus, pedoman mata pelajaran, pembelajaran, penilaian, dan buku teks.

\section{b. Pengembangan Program Pembelajaran}

Program adalah sebagai segala sesuatu yang dilakukan seseorang dengan harapan akan mendatangkan hasil atau pengaruh (Farida, Y. $T$, 2000). Program pembelajaran berarti rancangan atau perencanaan satu unit/ kesatuan kegiatan yang berkesinambungan dalam proses pembelajaran, yang memiliki tujuan dan melibatkan sekelompok orang (guru dan peserta didik) untuk mencapai tujuan pembelajaran yang telah ditetapkan.

Langkah awal yang perlu diadakan atau dihasilkan sebelum pelaksanaan pembelajaran adalah pengembangan program pembelajaran.
Pengembangan program pembelajaran pada dasarnya disesuaikan dengan kurikulum yang berlaku. Namun, perlu dipahami bahwa pengembangan program pada ketiga jenis kurikulum memiliki karakteristik masingmasing, namun pada dasarnya cenderung memiliki persamaan. Perlu pula dipahami bahwa model pengembangan program pembelajaran pada setiap jenis kurikulum, tidaklah merupakan sesuatu yang mesti menjadi acuan penuh, akan tetapi boleh saja diperkaya, divariasi, atau dikembangkan berdasarnya kebutuhan dengan tidak menyimpang makna konsep dasarnya. Pengembangan program pembelajaran dalam kajian ini dimaksudkan menelaah program pembelajaran yang telah dikembangkan dari masing-masing guru sesuai dengan karakteristik K.13, yaitu: (1) penyusunan pekan efektif, (2) program tahunan, dan semester, dan (3) RPP.

\section{c. Implementasi Kurikulum}

Implementasi kurikulum sasaran utamanya adalah menghasilkan pengalaman belajar bagi peserta didik. Untuk mewujudkan hal tersebut, guru harus lebih awal mempersiapkan rancangan pembelajaran dengan pedoman pada kurikulum yang berlaku. Penyusunan rancangan pelaksanaan pembelajaran, sebagai usaha untuk mewujudkan kegiatan nyata dalam proses pembelajaran.

Penyusunan rancangan pembelajaran merupakan tugas guru yang harus dikembangkan berdasar pada setiap $\mathrm{KD}$ /pokok bahasan. Rancangan pembelajaran ini dibuat sebelum guru melaksanakan pembelajaran dengan mengacu pada kurikulum. Dengan demikian, RPP adalah pedoman kerja pelaksanaan pembelajaran secara rinci. Komponen-komponennya adalah: SK, KD, Indikator, tujuan, materi, kegiatan, media dan sumber belajar, waktu, dan evaluasi (KTSP 2006). Selanjutnya, dalam kurikulum 2013 yang komponen-komponennya adalah $\mathrm{KI}, \mathrm{KD}$, Indikator, tujuan, materi, kegiatan, media dan sumber belajar, waktu dan evaluasi.

Rancangan pembelajaran yang telah dikemukakan di atas, merupakan gambaran pelaksanaan kurikulum yang telah disusun secara sistematis dan secara rinci pada setiap tahapan kegiatan pembelajaran di kelas. Namun perlu dipahami bahwa rancangan pembelajaran tersebut sifatnya relatif, dalam artian dapat saja mengalami perubahan disesuaikan dengan kondisi pada saat pelaksanaan pembelajaran, karena situasi dan kondisi nyata di lapangan 
adakalanya tidak sesuai dengan apa yang telah ditetapkan dalam rancangan pembelajaran.

\section{d. Evaluasi Kurikulum}

Istilah evaluasi dapat saja kita maknai upaya memahami dan memperbaiki suatu kegiatan. Evaluasi kurikulum berarti upaya memahami dan memperbaiki pelaksanaan kurikulum. Evaluasi kurikulum selalu mencakup penetapan baik-buruknya terhadap pelaksanaan kurikulum berdasarkan kriteria tertentu.

Evaluasi kurikulum merupakan salah satu langkah penting dalam rangkaian usaha memperoleh kurikulum yang baik, sebagai mata rantai dalam desain - implementasi - evaluasi kurikulum. Melalui evaluasi kurikulum itu, akan diperoleh balikan yang tepat untuk menyempurnakan yang sedang atau telah dikembangkan itu (dengan mengadakan berbagai revisi), atau sebaliknya menggantinya dengan mendesain kurikulum yang baru. Evaluasi kurikulum dapat dilakukan dalam rangka pengembangan kurikulum yaitu sebelum kurikulum itu diimplementasikan, tetapi dapat juga dilakukan setelah kurikulum diimplementasikan. Evaluasi kurikulum dalam tahap pengembangan dapat dilakukan dengan mereview "draft" kurikulum yang telah selesai disusun oleh tim pengembang dalam rangka uji kesahan uji coba terbatas (pilot testing) atau pun uji coba lapangan (field testing) dari kurikulum yang telah dikembangkan. Evaluasi pada tahap ini termasuk kawasan evaluasi perencanaan program. Evaluasi setelah kurikulum diimplementasikan termasuk kawasan evaluasi monitoring dan atau evaluasi dampak (impact) (Sulo, 1997). Tujuan evaluasi kurikulum adalah: (a) untuk menyempurnakan kurikulum, terutama pada tahap pengembangan, dan (b) untuk pengambilan keputusan tentang "nasib" suatu kurikulum (dipakai atau diabaikan).

\section{METODE PENELITIAN}

Jenis penelitian ini adalah penelitian deskriptif (descriptif research). Penelitian ini dilaksanakan dengan maksud untuk memahami masalah-masalah dalam pengembangan program pembelajaran, implementasi program, dan penilaian pelaksanaan program pembelajaran berbasis kurikulum 2013. Pendekatan penelitian adalah memadukan pendekatan kuantitatif dan kualitatif (mixed research design) (Cresswell 2004; Morgan 2007). Penggunaan pendekatan kuantitatif dan kualitatif tersebut, dijalankan untuk saling melengkapi sehingga hasil daripada satu pendekatan dapat diperkuat dan didukung oleh hasil daripada pendekatan lain (Johson \& Onwugbuzie 2004). Seagai prosedur penelitian melakukan analisis program pembelajaran berupa program tahunan, semester, RPP, bahan ajar, panduan, dan LKPD. Kegiatan ini dilakukan untuk mengtahui keadaan secara riil produk program pembelajaran yang telah dihasilkan oleh setiap guru dalam penerapan K.13. Program tersebut akan dilakukan kajian terhadap implementasi dan evaluasi K.13. Data yang diperlukan dalam kegiatan ini bersifat kuantitatif dan kualitatif. Data kuantitatif adalah data tentang dimensi-dimensi setiap program dan implementasi, dan evaluasi program pembelajaran dengan menggunakan lembar kajian. Sebagai sumber informasi adalah guru dan kepala sekolah. Data kualitatif adalah yang dikumpulkan dengan menggunakan tiga pendekatan, yaitu pengamatan dan wawancara, dan dokumentasi. Dapatan kajian digunakan sebagai data empiris tentang kondisi riil tentang program, pelaksanaan, dan evaluasi program berbasis K.13.

\section{HASIL \& PEMBAHASAN}

Hasil penelitian yang dipaparkan adalah: (1) Gambaran program pembelajaran berbasis K.13; (2) Gambaran implementasi pembelajaran berbasis K.13; dan (3) gambaran proses dan hasil evaluasi penerapan K.13.

\section{Gambaran program pembelajaran berbasis K.13}

Pengembangan program pembelajaran merupakan suatu tugas guru yang harus dilaksanakan sebelum pelaksanaan pembelajaran dilaksanakan. Hasil telaah pada empat tugas guru dalam pengembangan program yaitu: RPP, bahan ajar, panduan, dan LKS diperoleh gambaran, yaitu: 3,85. Bila dikonversi kedalam persen adalah $77 \%$. Bila dikonsultasikan pada kriteria berada pada kategori "Baik". Untuk jelasnya hasil analisis program pembelajaran yang telah dikembangkan guru dapat dilihat pada tabel 1 berikut:

Tabel 1 Gambaran hasil analisis program pembelajaran bagi guru sekolah dasar

\begin{tabular}{llll}
\hline No & Komponen & $\begin{array}{l}\text { Rata- } \\
\text { rata } \\
\text { Penilaian }\end{array}$ & Kategori \\
\hline 1 & Bahan Ajar & 3,90 & Baik \\
2 & Panduan & 3,90 & Baik \\
3 & RPP & 3,80 & Baik \\
4 & LKS & 3,00 & Baik
\end{tabular}

\begin{tabular}{lrr}
\hline Rata-rata & $\mathbf{3 , 8 5}$ & Baik \\
\hline
\end{tabular}


Pada tabel 1 menunjukkan bahwa Buku Ajar yang digunakan guru berkategori "baik". Indikasinya, yaitu: isi bahan ajar sesuai K.13; pemaparan isi objektif; uraian materi jelas; konsistensi konsep dan nilai-nilai karakter; sistematis; bahasa sesuai tingkat perkembangan anak; pemaparan materi singkat dan jelas; dan konsistensi materi pelajaran, RPP, dan LKPD. Panduan yang digunakan guru memaparkan: uraian tentang cara penggunaan bahan ajar; sistematika uraiannya jelas; informasi buku panduan jelas; petunjuk umum jelas; petunjuk khusus jelas; dan juga panduan membantu menggunakan bahan ajar. RPP yang akan dikembangkan guru yaitu: kejelasan identitas; memuat KI dan KD jelas; indikator menjabarkan muatan KD; tujuan operasional; materi konsisten dengan tujuan; kejelasan strategi; estimasi waktu sesuai kurikulum; konsistensi media dan sumber belajar dengan tujuan; penilaian melibatkan aspek kognitif, sikap dan psikomotor. LKS yang dikembangkan memaparkan: petunjuk jelas; konstruksi kalimat LKS jelas; substansi materi LKS mendukung pencapaian tujuan; sistematika penyajian materi LKS jelas; dapat mengaktifkan siswa belajar; langkah-langkah LKS jelas; estimasi waktu sesuai; media dan sumber belajar sesuai tujuan; dan kejelasan jenis penilaian.

\section{Gambaran Hasil Observasi penerapan K.13}

Hasil pengamatan penerapan K.13 pada 2 SD di Kecamatan Cina, yaitu: SD Inpres 6/80 Kawerang dan SDN 204 Walenrang pada kelas I hingga kelas VI pada taggal 17-18 Juli 2017 diperoleh informasi: 1) RPP yang digunakan masih bervariasi, yaitu: RPP buatan sendiri; buatan KKG/PKG; buatan diknas dan bahwa masih ada guru menggunakan RPP dengan bersumber dari internet. Pola pelaksanaan pembelajaran, yaitu kegiatan awal membaca doa belajar dan kurang guru melakukan apersepsi; tidak memotivasi belajar siswa pada awal pembelajaran; kurang menggambarkan langkah-langkah pembelajaran, dan tidak menyampaikan kompetensi yang akan diajarkan. Kegiatan inti guru cenderung menggunakan model kooperatif; media yang digunakan media jadi, dan tidak didapatkan guru menggunakan media yang didesain atau hasil rekayasa pengembangan sendiri. Penguasaan guru terhadap materi pelajaran sangat baik; pengelolaan ruang dan waktu cukup; menanamkan nilai-nilai karakter dalam proses dan akhir pembelajaran; melakukan penilaian kognitif; afektif dan psikomotor; dan cenderung pemberian $P R$ pada akhir pembelajaran.

\section{Gambaran proses dan hasil belajar penerapan K.13 bagi guru SD}

Berdasarkan hasil wawancara kepada Muliana, Rasyita, A. Abbas, Muliana, dan Sudarman yang dilakukan secara majelis pada tanggal 17 juli 2017 dipaparkan tentang berbagai fenomena dalam proses penerapan K.13, yaitu: terkait dengan masalah guru adalah kurang mengembangkan materi pelajaran; penerapan jenis-jenis penilaian; mengembangkan media, dan sarana pendukung lainnya. Aspek siswa sebagian kecil murid aktif kerja kelompok; kurang komunikatif, dan hasil belajar rata-rata masih kategori kurang.

\section{Pembahasan}

Hasil kajian kualitatif mendapatkan bahwa pada SD di Kecamatan Cina Kabupaten Bone telah menerapan K.13 mulai kelas I hingga kelas VI. Namun belum berjalan sebagaimana seharusnya, karena guru pada umumnya belum memperoleh pemahaman memadai terhadap pengembangan program, pelaksanaan, dan demikian pula dalam sistem penilaiannya. Dilihat dari pengembangan program pembelajaran dalam penerapan K.13 berada pada kategori "baik", namun program yang digunakan sangat bervariasi, yaitu masih ditemukan sebagian besar guru menggunakan program pembelajaran berupa RPP, bahan ajar, LKS, media, dan alat penilaian dengan menggunakan buatan pihak lain. Hal ini seiring keadaan kondisi riil yang terjadi bagi setiap tingkatan sekolah masih ditemukan guru mengalami masalah terkait dengan masalah guru dan masalah siswa dan beberapa masalah sarana prasana belajar yang belum berjalan sebagai mana mestinya. Kondisi seperti ini menunjukkan bahwa penguasaan konsep dan penerapan kurikulum 2013 belum memadai atau dengan kata lain masih perlu pembinaan kearah penyempurnaan dalam pelaksanaannya.

Temuan penelitian telah merealisasikan anjuran Menteri Pendidikan tentang pelaksanaan K.13 telah berjalan mulai kelas I hingga kelas VI namun belum berjalan seperti mana seharusnya. Demikian pula, anjuran pemerintah tentang pelaksanaan pendidikan nilai pada semua jenis dan peringkat pendidikan belum berjalan seperti mana sepatutnya (Ketetapan Presiden RI 2010). Bila dihubungkan dengan peranan guru sebagai perancang, pengembang, dan pelaksana kurikulum peringkat sekolah, maka guru belum 
merealisasikan sasaran pendidikan nilai secara terstruktur bagi murid di sekolah (Sukmadinata, 1997). Demikian pula, amanat dalam undangundang sistem pendidikan nasional Indonesia, bahwa tujuan pendidikan adalah pembentukan manusia utuh (holistik) yang meliputi pengembangan watak dan kepribadian yang baik (UU-Sisdiknas 2003).

Farida (2000) mengemukakan bahwa perlunya pengembangan program dengan harapan akan mendatangkan hasil atau pengaruh. Dalam hal Pengembangan program pembelajaran pada dasarnya disesuaikan dengan kurikulum yang berlaku. Namun, perlu dipahami bahwa pengembangan program pada ketiga jenis kurikulum memiliki karakteristik masing-masing, namun pada dasarnya cenderung memiliki persamaan. Perlu pula dipahami bahwa model pengembangan program pembelajaran pada setiap jenis kurikulum, tidaklah merupakan sesuatu yang mesti menjadi acuan penuh, akan tetapi boleh saja diperkaya, divariasi, atau dikembangkan berdasarkan kebutuhan dengan tidak menyimpang makna konsep dasarnya. Pengembangan program pembelajaran dalam kajian ini dimaksudkan menelaah program pembelajaran yang telah dikembangkan dari masing-pmasing guru sesuai dengan karakteristik K.13, yaitu: RPP, bahan ajar, panduan, dan LKS.

Program kurikulum berbasis K.13 menjadi keharusan bagi setiap guru dan menjadi dasar dalam implementasi kurikulum pada tingkat sekolah. Sasaran utamanya adalah menghasilkan pengalaman belajar bagi peserta didik. Untuk mewujudkan hal tersebut, guru harus lebih awal mempersiapkan rancangan pembelajaran dengan pedoman pada kurikulum yang berlaku. Penyusunan rancangan pelaksanaan pembelajaran, sebagai usaha mewujudkan kegiatan nyata dalam proses pembelajaran. Dalam sistem pelaksanaan program, seorang guru harus memanipulasi berbagai komponen sistem pembelajaran, agar pembelajaran dapat berjalan secara efisien dan efektif.

Kurikulum dalam implementasinya, perlu pula menelaah efek pelaksanaannya dengan melakukan kegiatan evaluasi, baik evaluasi terhadap proses dan maupun evaluasi terhadap hasil capaiannya. Evaluasi dalam kajian ini dapat kita maknai sebagai upaya memahami dan memperbaiki implementasi kurikulum. Evaluasi kurikulum berarti upaya memahami dan memperbaiki pelaksanaan kurikulum. Evaluasi kurikulum merupakan salah satu langkah penting dalam rangkaian usaha memperoleh kurikulum yang baik, sebagai mata rantai dalam desainimplementasi-evaluasi kurikulum.

Melalui evaluasi kurikulum akan diperoleh balikan yang tepat untuk menyempurnakan yang sedang atau telah dikembangkan itu (dengan mengadakan berbagai revisi), atau sebaliknya menggantinya dengan mendesain kurikulum yang baru. Evaluasi kurikulum dapat dilakukan dalam rangka pengembangan kurikulum yaitu sebelum kurikulum itu diimplementasikan, tetapi dapat juga dilakukan setelah kurikulum diimplementasikan. Evaluasi kurikulum dalam tahap pengembangan dapat dilakukan dengan mereview "draft" kurikulum yang telah selesai disusun oleh tim pengembang dalam rangka uji kesahan uji coba terbatas (pilot testing) atau pun uji coba lapangan (field testing) dari kurikulum yang telah dikembangkan. Evaluasi setelah kurikulum diimplementasikan termasuk kawasan evaluasi monitoring dan atau evaluasi dampak (impact) (Sulo, 1997). Tujuannya adalah (a) untuk menyempurnakan kurikulum, terutama pada tahap pengembangan, dan (b) untuk pengambilan keputusan tentang "nasib" suatu kurikulum. Selain itu evaluasi kurikulum dilakukan dalam rangka meningkatkan efektivitas program, pengorganisasian, dan pengelolaan program, dan dalam rangka keberhasilan implementasi kurikulum.

\section{KESIMPULAN \& SARAN}

Berdasakan hasil analisis data disimpulkan bahwa; (1) Hasil pengembangan program pembelajaran berbasis K.13 berada pada kategori "baik"; (2) Gambaran penerapan K.13 bervariasi, yaitu masih terdapat beberapa guru menggunakan program pembelajaran dengan buatan KKG, Diknas, dan yang bersumber dari internet. Implementasi kurikulum dalam pelaksanaan pembelajaran, yaitu berkategori "kurang"; dan (3) Gambaran proses dan hasil belajar penerapan K.13 bagi guru SD, berkategori "kurang". Kondisi seperti ini menunjukkan bahwa penguasaan konsep dan penerapan kurikulum 2013 belum memadai. Dengan demikian, supaya disarankan kepada para pengambil kebijakan hendaknya melakukan pembinaan dan pengembangan kearah penyempurnaan dalam pelaksanaan kurikulum tahun 2013. 


\section{DAFTAR PUSTAKA}

Abd. Haling. 2017. Belajar dan Pembelajaran. Makassar: Badan Penerbit UNM.

BSNP. 2006. Panduan Kurikulum Tingkat Satuan Pendidikan. Jakarta: BSNP.

Chamisijatin, L. et al. 2008. Pengembangan Kurikulum SD. Jakarta: Depdiknas Dirjend. Pendidikan Tinggi.

Cresswel, J. W. 2004. Educational research. Second Edition. New Jersay: Pearson Merril Prentice

Johson, R.B. \& Onwuegbuzie, A.J. 2004. Mexid method research: a research paradign whose time has come. Educational Researcher 33 (7): 14-26

Kemendikbud. 2013. Pedoman Pelatihan Implementasi Kurikulum 2013. Jakarta: Pusbang Tendik.

Morgan, D.L. 2007. Paradigms lost and pragtism reganet: methodological Implications of combining qualitative and quantitative method. Journal of Mixed Method Research 1 (1): 48-76

Muhaimin. 2010. Pengembangan Kurikulum Pendidikan Agama. Jakarta: Rajawali pers.

Mulyasa, E. 2003 Kurikulum Berbasis Kompetensi. Bandung: Remaja Rosdakarya.

Ornstein, A. C. \& Hunkins. F. (2009). Curriculum Foundations, Principles and Issues. Fourth Edition. New Jersey: Prentice Hall.

Republik Indonesia. 2003, Undang-undang nomor 20 tahun 2003, Tentang sistem pendidikan nasional. Jakarta: Depdiknas.

Republik Indonesia, 2010, Kebijakan nasional pembangunan karakter bangsa. Jakarta: Kemko kesejahteraan rakyat.

Republik Indonesia, 2010. Disain induk pendidikan karakter. Jakarta: Kemdiknas.

Sudirman, 2012. Implementasi Kurikulum Tingkat Satuan Pendidikan di sekolah dasar. Kualalumpur: UKM.

Suhaenah. 2001. Kurikulum Berbasis Kompetensi. Jakarta: Makalah.

Sulo Lipu La Sulo. 1997. Riviu Kurikulum. Ujung Pandang: FIP- IKIP Ujung Pandang.

Sukmadinata, Nana Syaodih. 1997. Pengembangan Kurikulum Teori dan Praktek. Bandung : PT Remaja Rosdakarya. 